\title{
Microstructure and thermal and functional properties of biodegradable films produced using zein
}

\author{
Crislene Barbosa de Almeida ${ }^{1 *}$, Elisângela Corradini ${ }^{2}$, Lucimara Aparecida Forato ${ }^{3}$, Raul Fujihara ${ }^{1}$ \\ and José Francisco Lopes Filho ${ }^{1}$
}

\author{
${ }^{1}$ Departamento de Engenharia e Tecnologia de Alimentos, Universidade Estadual Paulista - UNESP, \\ São José do Rio Preto, SP, Brazil \\ ${ }^{2}$ Universidade Tecnológica Federal do Paraná - UTFPR, Londrina, PR, Brazil \\ ${ }^{3}$ Empresa Brasileira de Pesquisa Agropecuária - EMBRAPA, São Carlos, SP, Brazil \\ *cris_zootecnista@hotmail.com
}

\begin{abstract}
Research is being conducted in an attempt to produce biodegradable packaging to replace plastic products, thereby reducing solid waste disposal. In this work, zein films were produced from vegetable oils (macadamia, olive and buriti) and from pure oleic acid. The surface of zein-based films made using oleic acid has a good lipid distribution. The high content of oleic acid produced a film with the greatest elongation at break $(8.08 \pm 2.71 \%)$ due to the greater homogeneity of the protein matrix. The different oils did not affect the glass transition temperature (Tg). Tg curves of films with fatty acids showed a reduction in mass at between 50 and $120{ }^{\circ} \mathrm{C}$ due to water evaporation. At $120{ }^{\circ} \mathrm{C}$ the weight loss was $3-5 \%$ and above this temperature further weight loss was observed with the highest loss being seen in the film made using pure oleic acid. In conclusion, although biodegradable films were produced using the four different oils, the film made from pure oleic acid has the best characteristics.
\end{abstract}

Keywords: biodegradable films, biomaterial, zein.

\section{Introduction}

Around the world, there is great concern about producing renewable materials from biomass. Due to environmental issues and sustainability, biomaterials produced from organic residues are the subject of several studies.

Among the many available raw materials suitable for the production of biodegradable products, starch and proteins are being used to create polymeric matrixes due to their good polymerization properties and because they are totally biodegradable. Both materials, similar to conventional synthetic polymers, are processed with the addition of plasticizers.

The biopolymer zein comprises $50 \%$ of the proteins in mature corn kernels ${ }^{[1]}$; it has hydrophobic characteristics due to its high content of apolar amino acids, in addition to its high degree of polymerization. Zein offers advantages as a raw material in the production of biomaterials, coatings and plastic applications as it is biodegradable and renewable ${ }^{[2-4]}$. It has been used to develop functional biodegradable packaging ${ }^{[5]}$, packages with antimicrobial agents ${ }^{[6-9]}$, packaging for periodontal biomaterials and substrates for cell culture ${ }^{[10]}$. Studies with zein have been carried out in respect to the regeneration of osseous tissues ${ }^{[11]}$, with nanoparticles used to improve the mechanical properties of films ${ }^{[12,13]}$ and edible film to increase the shelf life of pears ${ }^{[14]}$ and macadamia ${ }^{[15]}$.

The preparation of a film solution requires highmolecular-weight agents called matrix formers, solvents, plasticizers and, when necessary, a $\mathrm{pH}$ adjuster ${ }^{[16]}$. These components are used in different combinations to give films different characteristics.
Plasticizers are low-molecular-weight organic compounds used to reduce the intermolecular bonding forces, thereby giving high molecular mobility and flexibility to the film ${ }^{[17]}$. However, an excess of plasticizers results in a reduction of the mechanical properties of the film ${ }^{[18]}$. Glycerol is most frequently used even though it has hydrophilic properties ${ }^{[19,20]}$. The greater the amount of glycerol added to produce biopolymer-based films, the lower the stress rupture strength and the Young's modulus and so the elongation at break is higher. Many formulations include fatty acids, such as oleic, linoleic, stearic and palmitic fatty acids ${ }^{[21]}$.

Some edible vegetable oils have large amounts of oleic acid and so potentially, they can be used as plasticizers in the production of zein films. Of the oils containing fatty acids, buriti (Mauritia flexuosa), macadamia and olive oil are of great interest as the fatty acid levels are greater than $60 \%$.

Scanning electron microscopy (SEM) is the method most commonly used to evaluate the microstructure of biodegradable films. With this technique, it is possible to see whether the structure of the resulting biomaterial is uniform or if the components do not mix. Another important method to complement SEM in the analysis of the homogeneity of the matrix of films is optical microscopy (OM) which allows the characterization of the components by assessing their color and shape.

Thermal and mechanical analyses are important to determine the conditions under which the film can be used and the types of food that can be packaged. The glass transition temperature $(\mathrm{Tg})$ is of much interest to food 
scientists because it helps to explain the chemical and physical behavior of food systems ${ }^{[22]}$. The Tg of films is important as this characteristic limits the use of the material under extreme conditions, such as at freezing temperatures and during sterilization. The value of the $\mathrm{Tg}$ is primarily governed by the chemical composition particularly the presence of plasticizers, and secondarily by structural characteristics such as chain branching, crosslinking and crystallinity ${ }^{[23]}$. The Tg also provides information on the compatibility of the matrix constituents in a film, especially in the cases of blends/composites ${ }^{[24,25]}$. Thus, knowledge of the Tg of biodegradable films, specifically edible films, helps in the choice of the best storage conditions.

Good mechanical properties are also required and therefore, the elongation percentage and the tensile strength of the film need to be studied. The aim of this study was to produce biodegradable films of zein using pure oleic acid and edible vegetable oils (macadamia, buriti and olive oil) and to determine their microstructures and functional properties.

\section{Materials and Methods}

\subsection{Biodegradable films}

Zein (Freeman Industries, Inc. NY, USA) was used at a ratio of $20 \%(\mathrm{w} / \mathrm{v})$ in $75 \%$ ethanol solution. Other components were used in the following proportions in respect to $100 \mathrm{~g}$ of zein: $70 \mathrm{~g}$ edible vegetable oil (macadamia, olive or buriti) purchased at local shops (Vital Atman, La Violeteira and Rio Essências, respectively) or 70g of oleic acid (VETEC, Brazil) and 30g of glycerol (Merck, Brazil) as plasticizers and $5 \mathrm{~g}$ of Emustab ${ }^{\circledR}$ emulsifier (Duas Rodas Industrial Ltda., Brazil) to facilitate emulsification.

After combining the components, the filmogenic solution was heated to $62{ }^{\circ} \mathrm{C}$ while stirring at $250 \mathrm{rpm}$ to be subsequently cast on rectangular acrylic plates and maintained at $25{ }^{\circ} \mathrm{C}$ for 24 hours to dry. The films were peeled off the acrylic plates and stored inside a desiccator at $58 \%$ relative humidity until analyses.

\subsection{Composition analysis of the fatty acids of vegetable oils}

The fatty acid composition of oils was investigated at the Instituto de Tecnologia de Alimentos (ITAL), Campinas ${ }^{[26-29]}$.

\subsection{Scanning electron microscopy}

SEM was performed on $12-\mathrm{mm}$ round samples of film fixed under stubs using double-sided adhesive tape with conductive copper and covered with $35 \mathrm{~nm}$ of gold (EMITEC K550, UK). Samples were examined in duplicate by electronic microscopy (LEO $435 \mathrm{VP}, \mathrm{UK}$ ) at $15 \mathrm{kV}$ in a climate room.

\subsection{Optical microscopy}

Optical Microscopy (OM) was used to identify the compounds of the films. Duplicate samples were stained with Xylidine Ponceau ( $\mathrm{pH}=2.5)$ directly and dehydrated at $37^{\circ} \mathrm{C}$ for 24 hours (Odontobras ECB 1.2 Digital, Brazil). The samples were analyzed at room temperature using an optical microscope (Olympus BX 60, USA) with an image capture system (Olympus DP 71, USA). Different points in the sample were analyzed at $10 \times$ magnification.

\subsection{Analysis of differential scanning calorimetry}

Measurements were made using a differential scanning calorimeter (TA Instruments - TA Q100). Approximately 6-mg samples were subjected to pre-heating from $25{ }^{\circ} \mathrm{C}$ to $120^{\circ} \mathrm{C}$ to eliminate the thermal history. They were then reheated to $120{ }^{\circ} \mathrm{C}$ or $200{ }^{\circ} \mathrm{C}$ at a rate of $10{ }^{\circ} \mathrm{C} /$ minute under a nitrogen flow of $50 \mathrm{~mL} /$ minute. The Tg and melting temperature (Tm) were obtained from the minimum of the first derivative and minimum peak on the differential scanning calorimetry (DSC) curve, respectively.

\subsection{Thermogravimetric analysis}

The thermal stability of the materials was studied using a thermogravimetric analyzer (TGA - TA Instruments, Model Q500). All tests used a mass of approximately $7.0 \mathrm{mg}$ under a nitrogen flow of $50 \mathrm{~mL} /$ minute and heating rate of $10^{\circ} \mathrm{C} /$ minute within the temperature range of 25 to $900{ }^{\circ} \mathrm{C}$.

\subsection{Mechanical properties}

Tensile strength tests were performed with a Universal-Instron device (Model 5569, Instron Engineering Corp., Canton, MA) following the standard testing methods ASTM D882-91 ${ }^{[30]}$. Tensile strength at break ( $\sigma r)$, elongation at break (cr) and the Young's modulus (E) were determined.

\section{Results and Discussion}

\subsection{Appearance and thickness of the films}

After drying, the films were peeled off the rectangular acrylic plates and visual and tactile analyses were carried out in order to analyze only homogeneous samples in respect to thickness and without cracking. The color and thickness of the material should be uniform, there should be no brittle areas, and the material should be easy to handle. Films that did not have these characteristics were discarded.

The thickness was obtained by the arithmetic mean of six random points in different segments of the film using a digital micrometer (Digimess) at a resolution of $0.001 \mathrm{~mm}$. All films had uniform thicknesses from 0.19-0.20 $\pm 0.02 \mathrm{~mm}$.

\subsection{Characterization of edible vegetable oils}

The content of fatty acids of edible oils and the oleic acid used in the formulations are shown in Table 1.

Table 1. Fatty acid composition of plasticizing oils used in the formulation of zein films.

\begin{tabular}{lcccc}
\hline Plasticizers & $\begin{array}{c}\text { Oleic } \\
\mathbf{( \% )}\end{array}$ & $\begin{array}{c}\text { Linoleic } \\
\mathbf{( \% )}\end{array}$ & $\begin{array}{c}\text { Palmitic } \\
\mathbf{( \% )}\end{array}$ & $\begin{array}{c}\text { Palmitoleic } \\
(\mathbf{\%})\end{array}$ \\
\hline Oleic acid & 73.2 & 4.0 & 4.1 & 3.7 \\
Buriti oil & 35.1 & 53.6 & 5.5 & 0.1 \\
Macadamia oil & 61.0 & 1.7 & 7.9 & 16.8 \\
Olive oil & 64.7 & 17.1 & 11.3 & 0.7 \\
\hline
\end{tabular}


Fatty acid composition of edible oils and oleic acid are in accordance with the literature regarding the concentration of oleic acid (above $60 \%$ ) except for buriti oil. Buriti oil has less than $60 \%$ of oleic acid (35.1\%), but has a concentration of $53.6 \%$ of linoleic acid. Both acids produce materials with good flexibility and functional properties ${ }^{[31]}$.

\subsection{Scanning electron microscopy}

Micrographs (Figure 1) show that the films made with macadamia and buriti oil had similar structures with the homogeneous presence of rounded components that look like pores on the surface of the biomaterials. The lipid volume fraction in the dry film and the size of lipid aggregates are the main factors involved in the optical heterogeneity of the film matrix ${ }^{[32]}$. Films produced by the casting method show different morphological shapes due to drying with the side in contact with air presenting an irregular and opaque appearance and black globular deposits ${ }^{[33]}$.

The presence of globular deposits or pores was verified by the presence of rounded structures, showing that a continuous filmogenic matrix did not form. This observation was also reported in zein films ${ }^{[12,19,34-36]}$, chitosan film ${ }^{[37]}$ and pectin ${ }^{[38]}$.

The films produced with oleic acid (Figure 1c) and olive oil (Figure 1d) showed a smaller number of rounded forms and a significant reduction in the size of the fat globules thus demonstrating that a more homogenous matrix had been created.
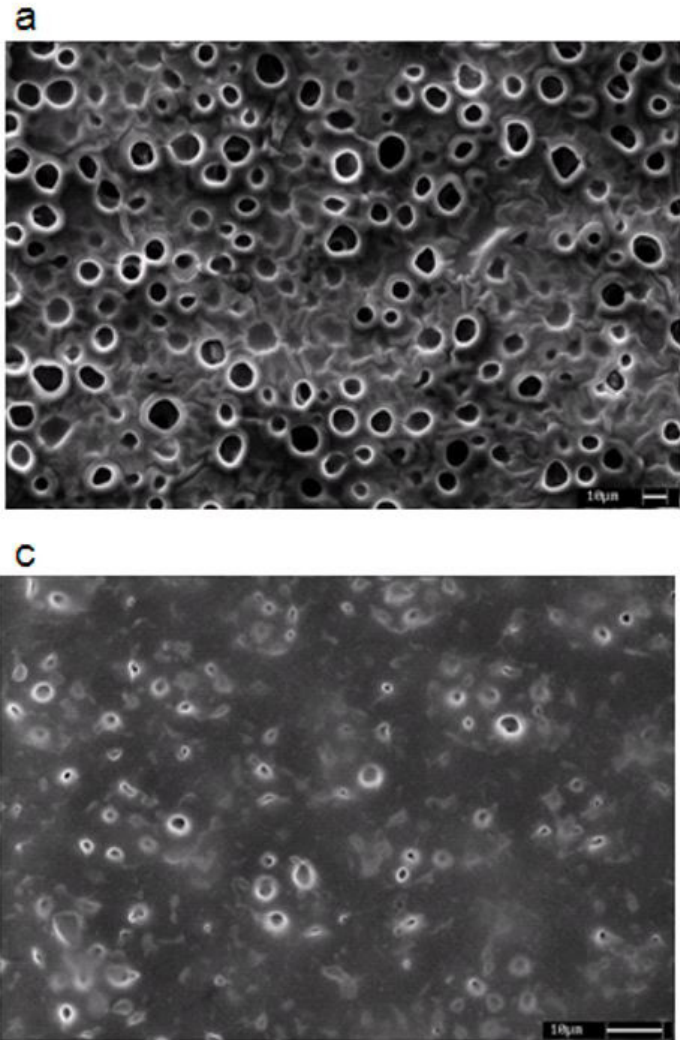

\subsection{Optical microscopy}

Optical microscopy was used to complement the SEM analysis of the homogeneity of the matrix of films in respect to the pore-like rounded forms similar to globular deposits. The Xylidine Ponceau technique provides two types of staining; red represents protein (zein) and white represents lipid globules.

Images of each sample are shown in Figures 2 and 3, with the scales of the micrographs being $4 \times(10 \mu \mathrm{m})$ and $10 \times(500 \mu \mathrm{m})$, respectively.

The micrographs show that zein film produced from oleic acid has greater homogeneity (Figure 3c, d) supporting the results of the SEM analysis. Moreover, the film made using macadamia oil (Figure 2c, d) was more homogeneous than the films of buriti (Figure 2a, b) and olive oil (Figure 3a, b). The arrangements of the fat globules in the films made with buriti and olive oil are more heterogeneous and larger, suggesting that a higher oleic acid content produces a more homogeneous material.

In addition, there is much streaking suggesting aligned fibrillar proteins which demonstrates that the incorporation of the plasticizer was not uniform in the matrix ${ }^{[34,39]}$. The homogeneity of the material seems to be correlated with the quantity (\%) of oleic acid in the oils because pure oleic acid produced the most uniform film with the best structural and functional characteristics and buriti oil the

\section{b}

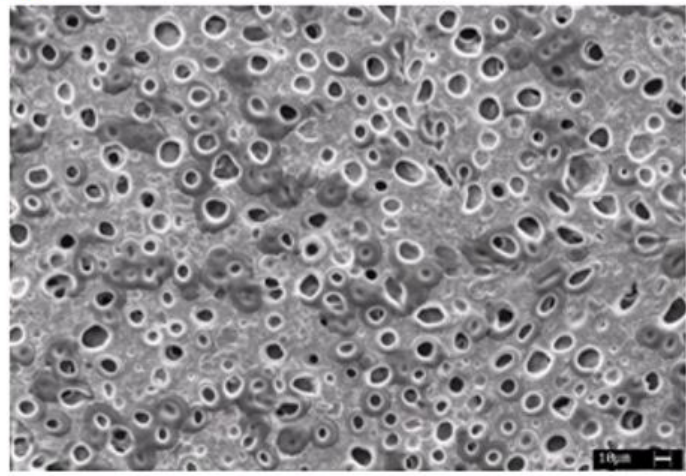

d

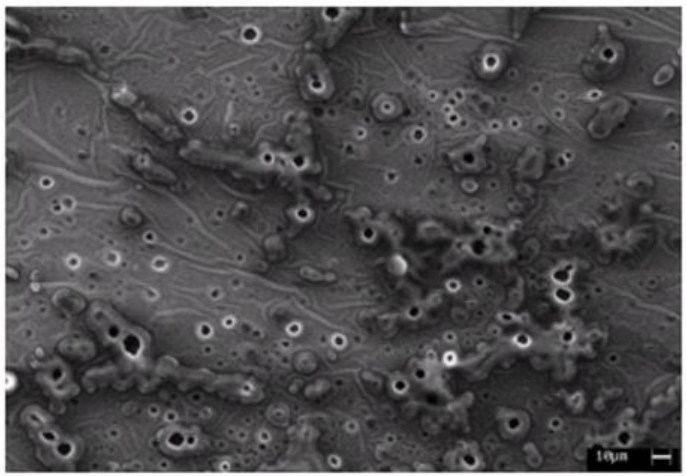

Figure 1. SEM micrographs of surfaces of: (a) zein- buriti oil; (b) zein-macadamia oil; (c) zein-oleic acid and (d) zein-olive oil. The increase indicative bar corresponds to $10 \mu \mathrm{m}$. 

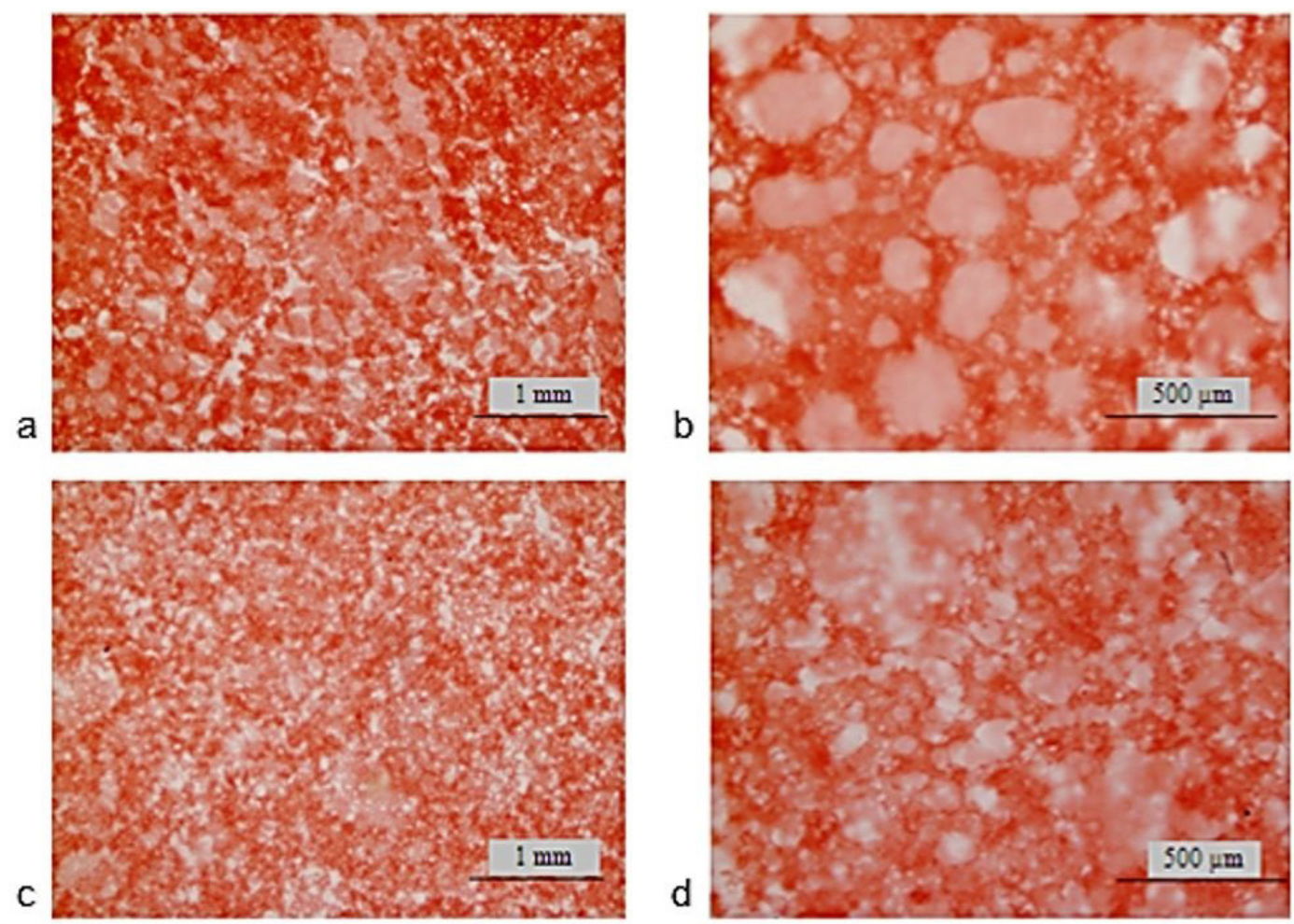

Figure 2. Image Optical Microscopy with Xylidine Ponceau for films: (a, b) zein-buriti oil and (c, d) zein-macadamia oil. The increase indicative bar corresponds $4 \times(10 \mu \mathrm{m})$ and $10 \times(500 \mu \mathrm{m})$.
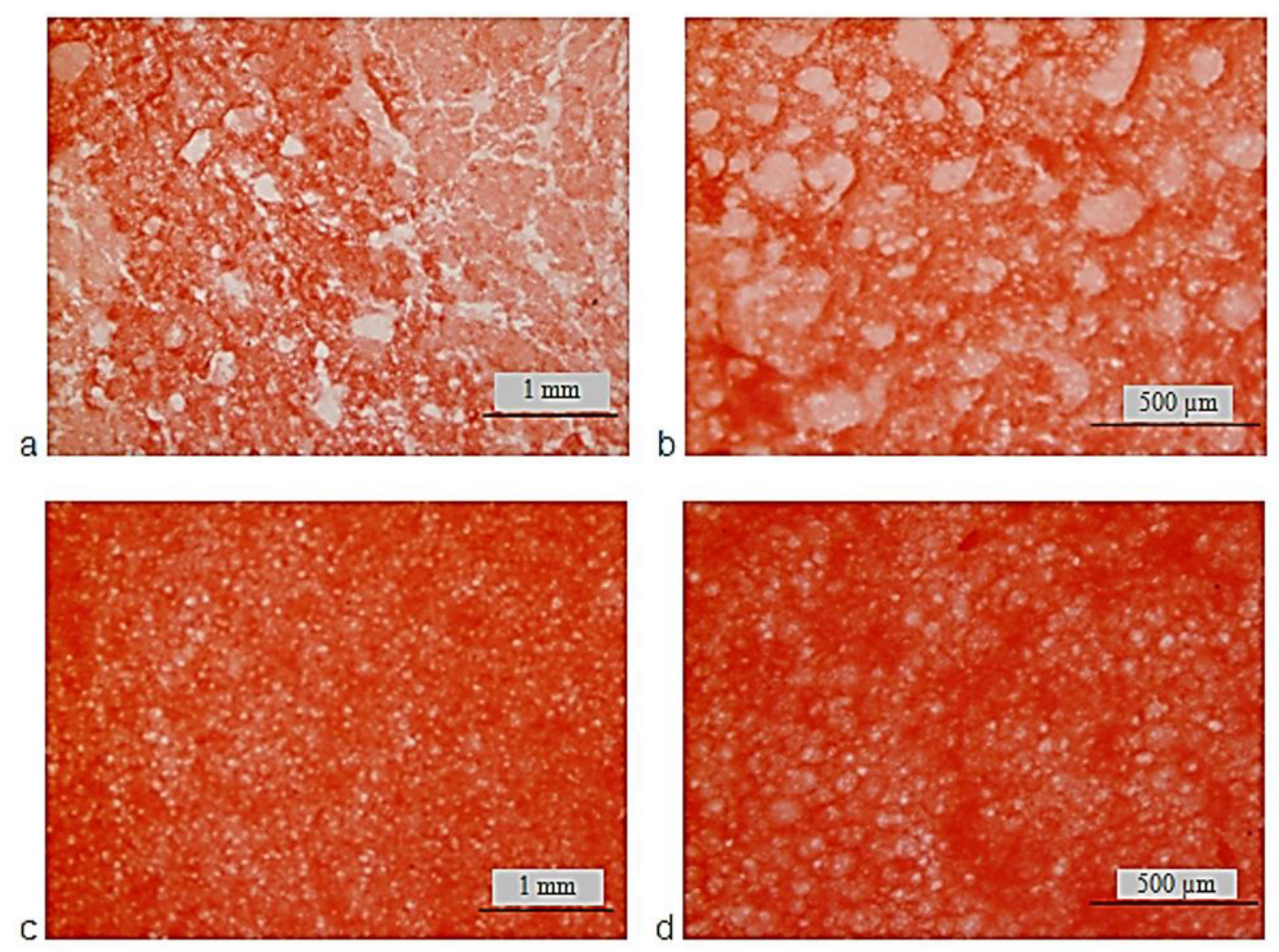

Figure 3. Image Optical Microscopy with Xylidine Ponceau for films: (a, b) zein-olive oil and (c, d) zein-oleic acid. The increase indicative bar corresponds $4 \times(10 \mu \mathrm{m})$ and $10 \times(500 \mu \mathrm{m})$. 
least uniform; Buriti oil has the lowest content of oleic acid (Table 1).

The optical microscopy analysis showed that the artifacts identified by SEM and believed to be pores are in fact fat globules in the film matrix. Almeida et al. ${ }^{[36]}$ also observed this in films produced with xanthan gum and zein.

\subsection{Differential scanning calorimetry}

Thermograms of the films show exothermic and endothermic peaks that characterize transitions or reactions that occurred during analysis, such as the $\mathrm{Tg}, \mathrm{Tm}$ and crystallization (Tc), among others. Figure 4 shows the DSC curves with the Tm and Tc and Figure 5 shows the expanded region of the DSC curves between $25^{\circ} \mathrm{C}$ and $100{ }^{\circ} \mathrm{C}$ of the materials studied.

The small peaks in the direction of exothermic heat flow occurring between $-55^{\circ} \mathrm{C}$ and $-35^{\circ} \mathrm{C}$, clearly seen in the films produced with buriti and macadamia oil, are attributed to the crystallization of the residual water (Tc) in the matrices ${ }^{[40]}$. Moreover, the peaks observed for all materials in the direction of endothermic heat flow, between $-30{ }^{\circ} \mathrm{C}$ and $3{ }^{\circ} \mathrm{C}$, are explained by the Tm of the oils.

The external factor that changes the Tg and $\mathrm{Tm}$ of a film is the presence of plasticizers in the liquid form ${ }^{[41]}$. By analyzing the composition of the fatty acids, it was found

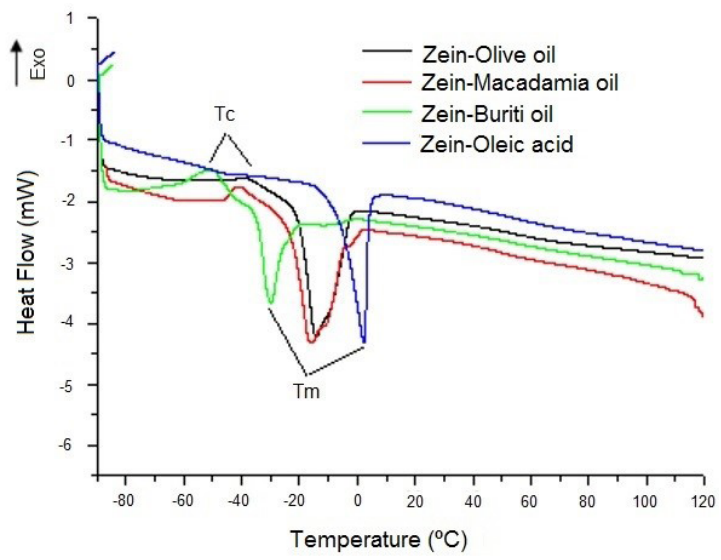

Figure 4. DSC curves of four zein biomaterials in temperature range of -90 to $90{ }^{\circ} \mathrm{C}$.

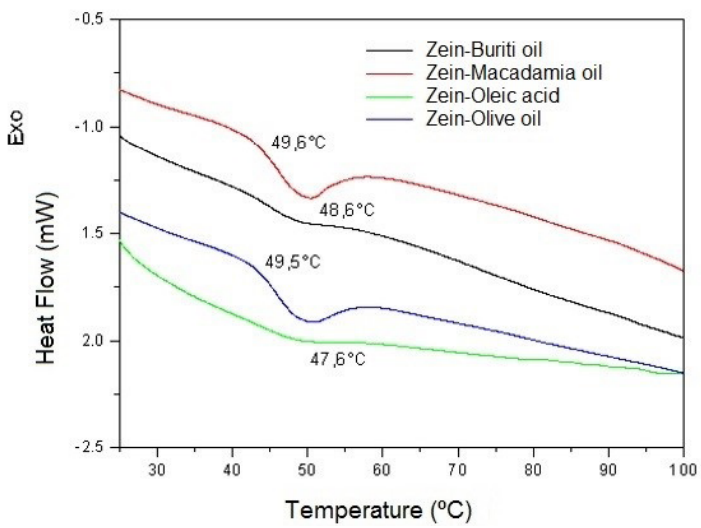

Figure 5. DSC curves showing Tg of zein films. that buriti oil contained a higher concentration of linoleic acid $(53.6 \%)$ than oleic acid (35.1\%). The Tm of oleic acid is $-2.2{ }^{\circ} \mathrm{C}$, while buriti oil has a lower $\operatorname{Tm}\left(-29.8^{\circ} \mathrm{C}\right)$. This is due to the lower content of oleic acid present in buriti oil; the film made from this oil has a different chemical structure.

These results confirm observations in literature who reported that oleic acid, which is the major component of the oils studied, presents a solid-solid phase transition of the order-disorder type $(\gamma \rightarrow \alpha)$ at $-2.2{ }^{\circ} \mathrm{C}^{[42]}$.

The $\mathrm{Tg}$ of pure zein powder is in the range of 150 to $180^{\circ} \mathrm{C}$; this decreases to $50{ }^{\circ} \mathrm{C}$ to $80^{\circ} \mathrm{C}$ when fatty acids or polyols are added ${ }^{[43,44]}$. In this study, the $\mathrm{Tg}$ of the zein films were in the range of $47^{\circ} \mathrm{C}$ to $50^{\circ} \mathrm{C}$ (Figure 5). The lowest value $\left(47.6^{\circ} \mathrm{C}\right)$ was for the zein film made with oleic acid and the highest temperatures were obtained for the films produced from macadamia and olive oil $\left(49.6{ }^{\circ} \mathrm{C}\right.$ and $49.5^{\circ} \mathrm{C}$, respectively).

Although there was no significant difference between the temperatures of the films, this result may be due to the purity and content of the oleic acid in the plasticizers as according to Lucas et al. ${ }^{[45]}$, larger amounts of plasticizer will reduce the $\mathrm{Tg}$.

\subsection{Thermogravimetric analysis}

Thermal stabilities of zein in its native form (powder), zein film without plasticizer and plasticized films were determined by thermogravimetry (TG). The TG curves and the first derivative or derivative thermogravimetry (DTG) for zein powder and the zein film prepared without plasticizers are shown in Figures $6 a$ and $6 b$, respectively.

The thermal behaviors of zein powder and zein film are quite similar. Initially, weight loss occurs in the temperature range of $25^{\circ} \mathrm{C}$ to $120^{\circ} \mathrm{C}$ due to the evaporation of water. Between $120^{\circ} \mathrm{C}$ and $200{ }^{\circ} \mathrm{C}$, there is a slight weight loss probably because of the evaporation of fatty acids. The main thermal degradation for zein powder and film occurs in the range of $270{ }^{\circ} \mathrm{C}$ to $415^{\circ} \mathrm{C}$. These results are in accordance with the literature ${ }^{[43,46]}$. There is also a slight shift to higher temperatures at the peak of the decomposition curve (DTG) obtained for the zein film compared to the peak of zein powder decomposition, which may be due to structural differences between zein powder and zein film.

Figures $7 \mathrm{a}$ and $7 \mathrm{~b}$ show the TG and DTG curves, respectively, for the plasticized zein films made with different vegetable oils. TG curves for all films showed a weight loss at $50{ }^{\circ} \mathrm{C}$ to $120^{\circ} \mathrm{C}$ due to water evaporation. The materials also exhibited a weight loss of $3-5 \%$ at $120^{\circ} \mathrm{C}$; these values are similar to those obtained by Corradini ${ }^{[47]}$. Successive weight losses are noted above $120^{\circ} \mathrm{C}$ for all materials.

Major thermal degradation of the films occurs in the range of $250^{\circ} \mathrm{C}$ to $405^{\circ} \mathrm{C}$. For all materials, the slight weight loss seen in the temperature range from $110{ }^{\circ} \mathrm{C}$ to $200{ }^{\circ} \mathrm{C}$ is probably due to the evaporation of fatty acids or glycerol because glycerol plasticizer, analyzed in isolation, has a decomposition temperature of around $213^{\circ} \mathrm{C}^{[48]}$. Note that the weight loss started at a lower temperature in the film made with pure oleic acid. These results are similar to those found in the literature for zein powder ${ }^{[43,46,47]}$. Small changes in the peaks at higher temperatures were also observed. This is 

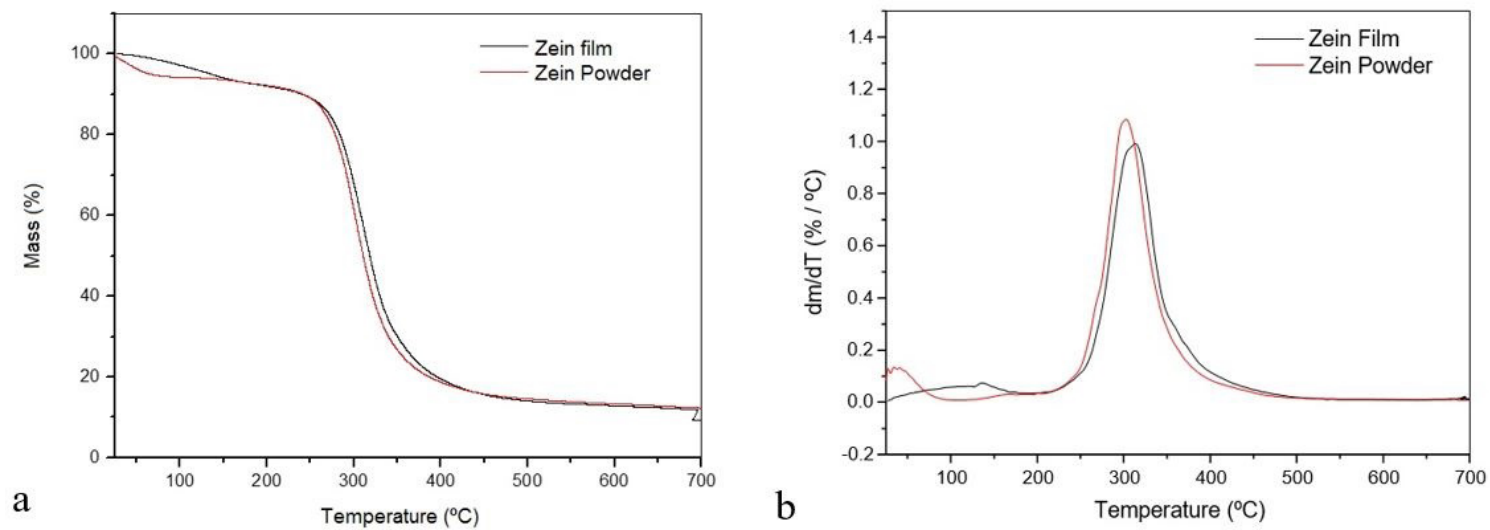

Figure 6. (a) TG curves for zein powder and zein film without plasticizer; (b) Curves of the first derivative (DTG) of Figure 7a.
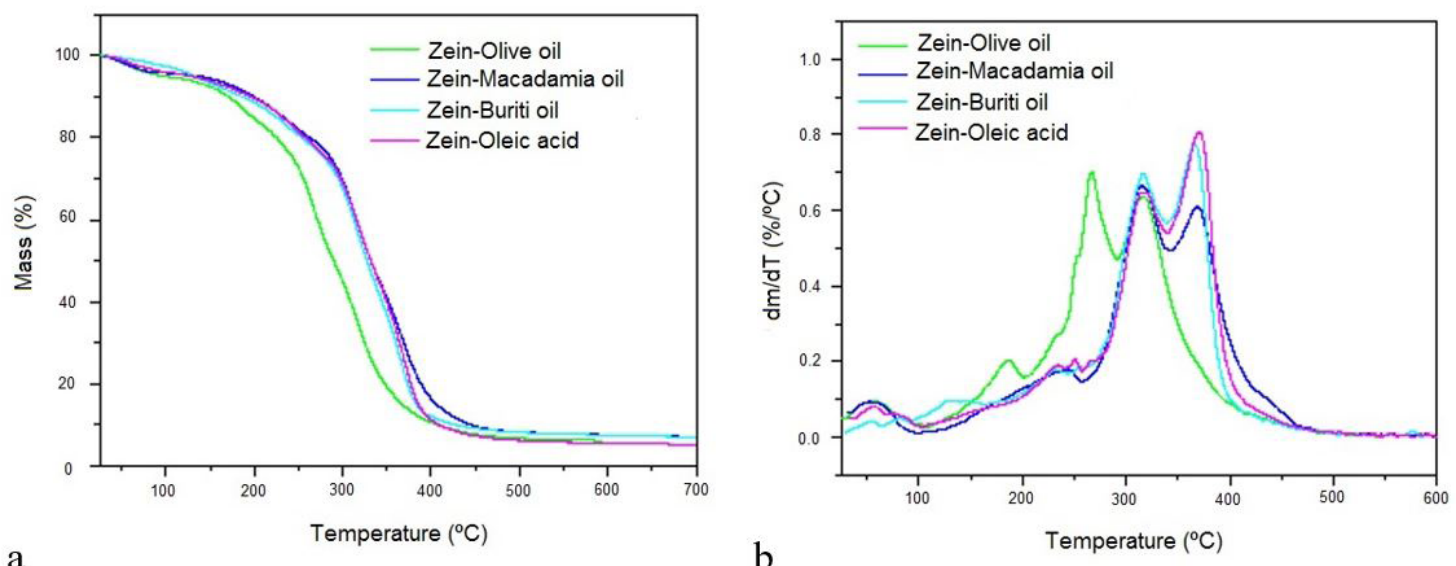

Figure 7. (a) TG curves; (b) DTG curve for zein films with plasticizers.

related to the decomposition curve obtained for zein films produced using buriti, macadamia and olive oil in relation to the peak of the control film decomposition. This result may be due to structural differences between oleic acid and other fatty acid components of the oils.

\subsection{Mechanical properties}

The mechanical properties of the films were affected by the type of plasticizer added. Table 2 shows the values found for tensile strength $\left(\sigma_{\mathrm{r}}\right)$, elongation at break $\left(\varepsilon_{\mathrm{r}}\right)$ and Young's modulus (E).

Films made with oleic acid had the highest percentage of elongation $(8.08 \% \pm 2.71)$ which is related to the elasticity of the materials. Similar results were reported ${ }^{[49]}$. The films made with macadamia oil had the lowest percentage of elongation at break $(0.93 \pm 0.24 \%)$ due to the lower homogeneity of the protein matrix. The percent of elongation decreases when fatty acids are not incorporated into the matrix ${ }^{[50,51]}$. This tendency is explained by the fact that lipids are unable to form a cohesive and continuous matrix.

The addition of lipids also affects the tensile strength and Young's modulus of the films; these values are the lowest when the concentration of lipids in the matrix is
Table 2. Tensile Strength $\left(\sigma_{\mathrm{r}}\right)$, Elongation at Break $\left(\varepsilon_{\mathrm{r}}\right)$ and Young's modulus (E) for the zein films.

\begin{tabular}{|c|c|c|c|}
\hline Film & $\begin{array}{c}\text { Tensile } \\
\text { strength }\left(\sigma_{\mathbf{r}}\right) \\
(\mathrm{MPa}) \\
\end{array}$ & $\begin{array}{c}\text { Elongation at } \\
\text { break }\left(\varepsilon_{\mathrm{r}}\right) \\
(\%) \\
\end{array}$ & $\begin{array}{c}\text { Young's } \\
\text { modulus (E) } \\
(\mathrm{MPa}) \\
\end{array}$ \\
\hline zein-oleic acid & $0.64 \pm 0.27$ & $8.08 \pm 2.71$ & $48.6 \pm 16.8$ \\
\hline zein-buriti oil & $1.66 \pm 0.29$ & $1.19 \pm 0.38$ & $278.28 \pm 17.67$ \\
\hline $\begin{array}{l}\text { zein-macadamia } \\
\text { oil }\end{array}$ & $1.30 \pm 0.45$ & $0.93 \pm 0.24$ & $278.86 \pm 28.06$ \\
\hline zein-olive oil & $1.02 \pm 0.26$ & $1.20 \pm 0.46$ & $202.59 \pm 13.71$ \\
\hline
\end{tabular}

optimized $^{[50,52,53]}$. Thus, the tensile results indicate that the control film (pure oleic acid) was the most homogeneous as the cohesion between the components of the matrix was the highest.

\section{Conclusions}

It was possible to produce biomaterials of zein using edible oils as plasticizers. Although all formulations formed biodegradable films, the film made from pure oleic acid had the best characteristics. Other techniques should be tested, such as ultrasonic frequency during the preparation 
of the filmogenic solution, to improve the formation of the matrix of the films and, consequently, improve the thermal and mechanical properties of the films.

\section{Acknowledgements}

The authors express their sincere thanks to the CAPES - "Brazilian Federal Agency for Support and Evaluation of Graduate Education within the Ministry of Education of Brazil" for the postgraduate fellowship and EMBRAPA - "Brazilian Agricultural Research Corporation” (São Carlos/Brazil) for analysis support.

\section{References}

1. Lending, C. R., \& Larkins, B. A. (1989). Changes in the zein compostion of protein bodies during maize endosperm development. The Plant Cell, 1(10), 1011-1023. PMid:2562552. $\mathrm{http} / / / \mathrm{dx}$.doi.org/10.1105/tpc.1.10.1011.

2. Zhang, H., \& Mittal, G. (2010). Biodegradable protein-based films from plant resources: a review. Environmental Progress \& Sustainable Energy, 29(2), 203-220. http://dx.doi.org/10.1002/ ep. 10463.

3. Corradini, E., Curti, P., Meniqueti, A., Martins, A., Rubira, A., \& Muniz, E. (2014). Recent advances in food-packing, pharmaceutical and biomedical applications of zein and zein-based materials. International Journal of Molecular Sciences, 15(12), 22438-22470. PMid:25486057. http://dx.doi. org/10.3390/ijms151222438.

4. Shi, W., \& Dumont, M. J. (2014). Review: bio-based films from zein, keratin, pea, and rapeseed protein feedstocks. Journal of Materials Science, 49(5), 1915-1930. http://dx.doi. org/10.1007/s10853-013-7933-1.

5. Shi, K., Yu, H., Lee, T.-C., \& Huang, Q. (2013). Improving ice nucleation activity of zein film through layer-by-layer deposition of extracellular ice nucleators. ACS Applied Materials \& Interfaces, 5(21), 10456-10464. PMid:24106783. http:// dx.doi.org/10.1021/am4016457.

6. Li, K.-K., Yin, S.-W., Yang, X.-Q., Tang, C.-H., \& Wei, Z.-H. (2012). Fabrication and characterization of novel antimicrobial films derived from thymol-loaded zein-sodium caseinate (SC) nanoparticle. Journal of Agricultural and Food Chemistry, 60(46), 11592-11600. PMid:23121318. http://dx.doi.org/10.1021/ jf302752v.

7. Wu, Y., Luo, Y., \& Wang, Q. (2012). Antioxidant and antimicrobial properties of essential oils encapsulated in zein nanoparticles prepared by liquid-liquid dispersion method. LebensmittelWissenschaft + Technologie, 48(2), 283-290. http://dx.doi. org/10.1016/j.1wt.2012.03.027.

8. Khairuddin, N., \& Muhamad, I. I. (2013). Potential of antimicrobial film containing thymol with $\mathrm{pH}$ indicator to increase biosafety of packed food. Jurnal Teknologi, 62(2), 31-34. http://dx.doi.org/10.11113/jt.v62.1875.

9. Ghasemi, S., Javadi, N. H. S., Moradi, M., \& KhorsraviDarani, K. (2015). Application of zein antimicrobial edible film incorporatating Zataria multiflora boiss essential oil for preservation of Iranian ultrafiltered Feta cheese. African Journal of Biotechnology, 14(24), 2014-2021. http://dx.doi. org/10.5897/AJB2014.13992.

10. Liu, J., Wu, J.-J., Li, N., Yang, F.-Y., \& Xu, Y.-Z. (2010). Periodontal tissue engineered scaffold materials fabricated with zein. Journal of Clinical Rehabilitative Tissue Engineering Research, 14(42), 7873-7877. Retrieved in 2016, November 30, from http://en.cnki.com.cn/Article_en/CJFDTOTALXDKF201042026.htm
11. Zhou, P., Xia, Y., Cheng, X., Wang, P., Xie, Y., \& Xu, S. (2014). Enhance bone tissue regeneration by antibacterial and osteoinductive silica-HACC-zeincomposite scaffolds loaded with rrBMP-2. Biomaterials, 35(38), 10033-10045. PMid:25260421. http://dx.doi.org/10.1016/j.biomaterials.2014.09.009.

12. Tavares, L. L., Almeida, C. B., Caruso, Í. P., Cornélio, M. L., \& Lopes, J. F., Fo. (2012). Effect of modified clays on the structure and functional properties of biofilm produced with zein. Food Science and Technology, 32(2), 314-322. http:// dx.doi.org/10.1590/S0101-20612012005000056.

13. Ribeiro, W. X., Lopes, J. F., Fo., Cortes, M. S., \& Tadini, C. C. (2015). Characterization of biodegradable film based on zein and oleic acid added with nanocarbonate. Ciência Rural, 45(10), 1890-1894. http://dx.doi.org/10.1590/0103-8478cr20141391.

14. Scramin, J. A., Britto, D., Forato, L. A., Bernardes-Filho, R., Colnago, L. A., \& Assis, O. B. G.. (2011). Characterization of zein-oleic acid zein films and application in fruit coating. International Journal of Food Science \& Technology, 46(10), 2145-2152. http://dx.doi.org/10.1111/j.1365-2621.2011.02729.x.

15. Colzato, M., Scramin, J. A., Forato, L. A., Colnago, L. A., \& Assis, O. B. G. (2011). 1H NMR investigation of oil oxidation in macadamia nuts caoted with zein-based films. Journal of Food Processing and Preservation, 35(6), 790-796. http:// dx.doi.org/10.1111/j.1745-4549.2011.00530.x.

16. Cheng, S. Y., Wang, B. J., \& Weng, Y. M. (2015). Antioxidant and antimicrobial edible zein/chitosan composite films fabricated by incorporation of phenolic compounds and dicarboxylic acids. Lebensmittel-Wissenschaft + Technologie, 63(1), 115121. http://dx.doi.org/10.1016/j.lwt.2015.03.030.

17. Matta, M., Jr., Sarmento, S. B. S., Sarantopoulos, C. I. G. L., $\&$ Zocchi, S. S. (2011). Propriedades de barreira e solubilidade de filmes de amido de ervilha associado com goma xantana e glicerol. Polímeros: Ciência e Tecnologia, 21(1), 67-72. http:// dx.doi.org/10.1590/S0104-14282011005000011.

18. Erickson, D. P., Renzetti, S., Jurgens, A., Campanella, O. H., \& Hamaker, B. R. (2014). Modulating state transition and mechanical properties of viscoelastic resins from maize zein through interactions with plasticizers and co-proteins. Journal of Cereal Science, 60(3), 576-583. http://dx.doi.org/10.1016/j. jcs.2014.08.001.

19. Pena-Serna, C., \& Lopes Filho, J. F. (2013). Influence of ethanol and glycerol concentration over functional and structural properties of zein-oleic acid films. Materials Chemistry and Physics, 142(2-3), 580-585. http://dx.doi.org/10.1016/j. matchemphys.2013.07.056.

20. Liang, J., Xia, Q., Wang, S., Li, J., Huang, Q., \& Ludescher, R. D. (2015). Influence of glycerol on the molecular mobility, oxygen permeability and microstructure of amorphous zein films. Food Hydrocolloids, 44, 94-100. http://dx.doi.org/10.1016/j. foodhyd.2014.09.002.

21. Mali, S., Grossmann, M. V. E., Garcia, M. A., Martino, M. N., \& Zaritzky, N. E. (2006). Effects of controlled storage on thermal, mechanical and barrier properties of plasticized films from different starch sources. Journal of Food Engineering, 75(1-4), 453-460. http://dx.doi.org/10.1016/j.jfoodeng.2005.04.031.

22. Verdolotti, L., Oliviero, M., Lavorgna, M., Iozzino, V., Larobina, D., \& Iannace, S. (2015). Bio-hybrid foams by silsesquioxanes cross-linked thermoplastic zein films. Journal of Cellular Plastics, 51(1), 75-87. http://dx.doi.org/10.1177/0021955X14529138.

23. Rogers, C. E. (1985). Permeation of gases and vapors in polymer. In J. Comyn (Ed.). Polymer permeability (pp. 11-73). Netherlands: Springer.

24. Corradini, E., Pineda, E. A. G., \& Hechenleitner, A. A. W. (1999). Lignin-poly (vinyl alcohol) blends studied by thermal analysis. Polymer Degradation \& Stability, 66(2), 199-208. http://dx.doi.org/10.1016/S0141-3910(99)00066-X. 
25. Haines, P. J. (2012). Thermal methods of analysis: principles, applications and problems. Netherlands: Springer.

26. Hartman, L., \& Lago, R. C. A. (1973). Rapid preparation of fatty acid methy esters from lipids. Laboratory Practice, 22(6), 475-476. PMid:4727126.

27. Holland, B., Welch, A. A., \& Buss, D. H. (2002). Vegetable dishes. In Royal Society Of Chemistry - RSC. McCance and widdowson's the composition of foods: 6th summary edition. Cambridge: RSC.

28. Horwitz, W. (2005). Official methods of analysis of Association of Official Analytical Chemists (18th ed., 2, 41, met. 996.06, 20). Washington: AOAC.

29. Firestone, D. (2006). Official methods and recommended practices of the American Oil Chemistry Society (5th ed., AOCS Official method Ce 1e-91, Ce 1f-96, Ce1-62). Champaign: AOCS.

30. American Society for Testing and Materials - ASTM. (2002). D882-91: Annual Book of American Society for Test and Material Standards, standard test methods for tensile strength of plastic sheets. Philadelphia: The Society. http://dx.doi.org/10.1520/ D0882-10.

31. Ha, T. T., \& Padua, G. W. (2001). Effect of extrusion processing of properties of zein-fatty acids sheets. Transactions of the ASAE. American Society of Agricultural Engineers, 44(5), 1223-1228. http://dx.doi.org/10.13031/2013.6416.

32. Villalobos, R., Chanona, J., Hernández, P., Gutiérrez, G., \& Chiralt, A. (2005). Gloss and transparency of hydroxypropyl methylcellulose films containing surfactantes as affeted by their microstructure. Food Hydrocolloids, 19(1-6), 53-61. http://dx.doi.org/10.1016/j.foodhyd.2004.04.014.

33. Padua, G. W., \& Wang, Q. (2002). Formation and properties of corn zein films and coatings. In A. Gennadios. Protein-based films and coatings (pp. 43-67). London: CRC Press.

34. Ghanbarzadeh, B., Musavi, M., Oromiehie, A. R., Rezayi, K., Razmi Rad, E., \& Milani, J. (2007). Effect of plasticizing sugars on water vapor permeability, surface energy and microstructure properties of zein films. Lebensmittel-Wissenschaft + Technologie, 40(7), 1191-1197. http://dx.doi.org/10.1016/j.lwt.2006.07.008.

35. Corradini, E., Carvalho, A. J. F., Curvelo, A. A. S., Agnelli, J. A. M., \& Mattoso, L. H. C. (2007). Preparation and characterization of thermoplastic starch/zein blends. Materials Research, 10(3), 221-231. http://dx.doi.org/10.1590/S1516-14392007000300002.

36. Almeida, C. B., Catelan, K. T., Cornélio, M. L., \& Lopes, J. F., Fo. (2010). Morphological and structural characteristics of zein biofilms with added xanthan gum. Food Technology and Biotechnology, 48(1), 19-27. Retrieved in 2016, November 30, from http://www.ftb.com.hr/images/pdfarticles/2010/JanuaryMarch/48-19.pdf

37. Hafsa, J., Smach, M., Khedher, M. R. B., Charfeddine, B., Limem, K., Majdoub, H., \& Rouatbi, S. (2016). Physical, antioxidant and antimicrobial properties of chitosan films containing Eucalyptus globulus essential oil. LebensmittelWissenschaft + Technologie, 68, 356-364. http://dx.doi. org/10.1016/j.1wt.2015.12.050.

38. Batista, J. A., Tanada-Palmu, P. S., \& Grosso, C. R. F. (2005). Efeito da adição de ácidos graxos em filmes à base de pectina. Food Science and Technology, 25(4), 781-788. http://dx.doi. org/10.1590/S0101-20612005000400025.

39. Lai, H.-M., \& Padua, G. W. (1997). Properties and microstructure of plasticized zein films. Cereal Chemistry, 74(1-6), 771-775. http://dx.doi.org/10.1094/CCHEM.1997.74.6.771.

40. Ghanbarzadeh, B., Oromiehie, A. R., Musavi, M., D-Jomeh, Z. E., Rad, E. R., \& Milani, J. (2006). Effect of plasticizing sugars on rheological and thermal properties of zein films. Food Research International, 39, 1-10, 882-890. http://dx.doi. org/10.1016/j.foodres.2006.05.011.

41. Canevarolo, S. V., Jr. (2010). Ciência dos Polímeros: um texto básico para tecnólogos e engenheiros. 3rd ed. São Paulo: Artliber.

42. Tandon, G., Förster, G., Neubert, R., \& Wartewig, S. (2000). Phase transitions in oleic acid as studied by $\mathrm{X}$-ray diffraction and FT-Raman spectroscopy. Journal of Molecular Structure, 524(13), 201-215. http://dx.doi.org/10.1016/S0022-2860(00)00378-1.

43. Magoshi, J., Nakamura, S., \& Murakami, K.-I. (1992). Structure and physical properties of seed proteins. I. Glass transition and crystallization of zein protein from corn. Journal of Applied Polymer Science, 45(11), 2043-2048. http://dx.doi.org/10.1002/ app.1992.070451119.

44. Wang, Q., Crofts, A. R., \& Padua, G. W. (2003). Protein-lipid interactions in zein films investigated by surface plasmon resonance. Journal of Agricultural and Food Chemistry, 51(25), 7439-7444. PMid:14640596. http://dx.doi.org/10.1021/ jf0340658.

45. Lucas, E. F., Soares, B. G., \& Monteiro, E. (2001). Caracterização de polímeros: determinação de peso molecular e análise térmica (Série Instituto de Macromoléculas). Rio de Janeiro: e-papers.

46. Oliviero, M., Di Maio, E., \& Iannace, S. (2010). Effect of molecular structure on film blowing ability of thermoplastic zein. Journal of Applied Polymer Science, 115(1), 277-287. http://dx.doi.org/10.1002/app.31116.

47. Corradini, E. (2004). Desenvolvimento de blendas poliméricas de zeina e amido de milho (Master's thesis). Universidade de São Paulo, São Carlos.

48. Schlemmer, D., Sales, M. J. A., \& Resck, I. S. (2010). Preparação, caracterização e degradação de blendas PS / TPS usando glicerol e óleo de buriti como plastificantes. Polímeros: Ciência e Tecnologia, 20(1), 6-13. http://dx.doi.org/10.1590/ S0104-14282010005000002.

49. Pena-Serna, C., \& Lopes, J. F., Fo. (2015). Biodegradable zein-based blend films: structural, mechanical and barrier properties. Food Technology and Biotechnology, 53(3), 348353. PMid:27904368.

50. Péroval, C., Debeaufort, F., Despré, D., \& Voilley, A. (2002). Edible arabinoxylan-based films. 1. Effects of lipid type on water vapor permeability, film structure, and other physical characteristics. Journal of Agricultural and Food Chemistry, 50(14), 3977-3983. PMid:12083869. http://dx.doi.org/10.1021/ jf0116449.

51. Yang, L., \& Paulson, A. T. (2000). Effects of Lipids on Mechanical and Moisture Barrier Properties of Edible Gellan Film. Food Research International, 33(7), 571-578. http:// dx.doi.org/10.1016/S0963-9969(00)00093-4.

52. Debeaufort, F., Quezada-Gallo, J. A., Delporte, B., \& Voilley, A. (2000). Lipid hydrophobicity and physical state effects on the properties of bilayer edible films. Journal of Membrane Science, 180(1), 47-55. http://dx.doi.org/10.1016/S03767388(00)00532-9.

53. Chang, C., \& Nickerson, M. T. (2014). Effect of plasticizertype and genipin on the mechanical, optical, and water vapor barrier properties of canola protein isolate-based edible films. European Food Research and Technology, 238(1), 35-46. http:// dx.doi.org/10.1007/s00217-013-2075-x.

Received: Nov. 30, 2016 Accepted: Apr: 02, 2017 